\title{
Paenula storyi, a new genus and species related to Ixodia and Haeckeria (Asteraceae: Gnaphalieae)
}

\author{
A.E. Orchard \\ Centre for Plant Biodiversity Research, CSIRO Plant Industry, GPO Box 1600, Canberra \\ ACT 2601, Australia
}

\begin{abstract}
A plant collected incidentally 40 years ago SSE of Wollar in the Central Western Slopes district of New South Wales is shown to represent a new genus and species, combining the paleae characteristics of Ixodia with the leaf characteristics of Haeckeria s.str. and the phyllary characteristics of Cassinia and Haeckeria. As in Haeckeria, and some species of Odixia and Cassinia, it lacks a pappus. The genus Paenula and species Paenula storyi are described and illustrated, the few available details of ecology summarised, and inter-relationships discussed.
\end{abstract}

\section{Introduction}

In an earlier paper (Orchard 1981) I discussed character distribution in a range of genera related to Ixodia (Odixia, Haeckeria, Ammobium, Cassinia and Ozothamnus (as Helichrysum)). It was shown that this group of shrubby Asteraceae showed a braided series of inter-relationships, where characters usually thought to be diagnostic (presence and absence of pappus, presence and absence of paleae, production of a showy 'petal-like' reflexed tip to the inner phyllaries, etc) seemed to be segregating independently of each other. That paper resulted in the description of a new genus Odixia, to accommodate two Tasmanian species formerly placed in Ixodia. Odixia is separated from Ixodia in having only 5-6 florets per capitulum, membranous phyllaries, of which the innermost are \pm linear with a narrow white tip, and either lacking paleae between the florets, or paleae flat, linear or filiform. Ixodia has 20-30 florets per capitulum, green \pm fleshy phyllaries, of which the innermost are clawed with a broad white hooded tip, and the paleae wrap around and envelop the florets. There were other minor character differences: for example, in Ixodia the abscissing fruits leave peg-like scars on the receptacle, while in Odixia the scars are rough but not peg-like. It was suggested that Odixia was probably more closely related to Cassinia and Haeckeria than to Ixodia. Odixia, Cassinia and Haeckeria share a \pm woody shrubby habit, membranous phyllaries which are not noticeably expanded at the tips into petaloid appendages, and paleae which, when present, are planar or at most, longitudinally fluted. Ixodia is a short lived shrub, has green fleshy phyllaries, well 
developed showy petaloid terminal appendages on the inner phyllaries, and paleae which wrap around the achene and base of the floret. Ixodia was last revised by Copley (1982).

In a separate paper (Orchard 2004) I discuss the variation and limits of Haeckeria, reducing that genus to just two species, $H$. punctulata and $H$. cassiniiformis. Thus reduced, Haeckeria is defined as comprising short-lived woody shrubs bearing fleshy trigonous leaves with embedded dark glands, capitula of 1, 2 or 3 bisexual florets with no paleae, florets epappose, and phyllaries membranous or cartilaginous, each narrowly ovate, slightly hooded, incurved at tip and lacking showy petaloid appendages.

In the course of preparing the above paper and another on Cassinia, I came across a specimen from New South Wales which caused me to revisit the Ixodia complex. This specimen was collected almost accidentally in 1961 by R. Story. He had collected specimens of Cassinia quinquefaria from south-south-east of Wollar, from an unnamed 'nephaline hill'. In addition to flowering material of the Cassinia he collected some other material that he thought was fruiting material of the same species. However, during processing at the National Herbarium of New South Wales it was noted that the fruiting material did not belong to C. quinquefaria, and it was annotated 'Cassinia sp. nov.' As the material was rather scrappy, it lay in limbo for the next 40 years.

\section{Taxonomy}

Examination of the above material in the course of my Cassinia revision revealed that it was not part of that genus. The leaves are terete-trigonous, rugose, with an obscure midrib, and the leaves have, on all three surfaces, deeply sunken dark pit-glands. The capitula are Cassinia-like, with white phyllaries all slightly hooded, incurved at the tip, spirally arranged, and lacking a showy reflexed petaloid tip. The florets are all bisexual, epappose, few in number ( 6 per capitulum) and each is enclosed in a stiff hyaline sheath formed by its subtending palea.

In its leaf characters (trigonous with dark sunken glands) this plant most closely resembles Haeckeria s. str. Some plants of Ixodia can also exhibit dark sunken pitglands, but the leaves in that genus are usually flattened, never trigonous in section. In its capitulum structure the new species mimics Cassinia, and it was this allied with its \pm terete leaves which undoubtedly led to its temporary identification as Cassinia sp. nov. However, similar inflorescence structures and capitulum structures are also found in Ozothamnus and in Haeckeria s.str., and the leaf anatomy of Paenula is not reflected in any species of Cassinia, where the leaves are uniformly dorsiventral and never exhibit dark sunken pit-glands. The interim close identification of this taxon with Cassinia is thus to be disregarded. In lacking a pappus it also resembles Haeckeria, Odixia and some anomalous Cassinia species (see Orchard, in prep.), but in its peculiar sheathing paleae it is obviously linked to Ixodia.

The Story material clearly represents a new species, and it does not fit well in any of the existing genera. Expansion of the limits of any of them to accommodate it would introduce unsatisfactory anomalies elsewhere. The most satisfactory solution seems to be to recognise it as a distinct genus, sister to Ixodia (or perhaps Haeckeria), and distinguished from its near relatives as follows: 
1. Paleae forming a stiff hyaline sheath around the achenes and base of the florets; leaves often with dark sunken pit-glands.

2. Capitula of 20-30 florets; phyllaries green and subfleshy, leaves decurrent, terete or flattened but not trigonous Ixodia

2: Capitula of c. 6 florets; phyllaries white, membranous to cartilaginous; leaves sessile, not decurrent, trigonous Paenula

1: Paleae (if present) flat or at most longitudinally fluted; leaves glabrous, pubescent or with dark sunken pit-glands; phyllaries membranous to cartilaginous

3. Pappus absent

4. Inner phyllaries with spreading petaloid tips; leaves dorsiventral with well defined midrib, glabrous or pubescent but never with dark sunken pit-glands; paleae present or absent

4: Inner phyllaries lacking spreading petaloid tips

5. Leaves trigonous, lacking prominent midrib below, with dark sunken pit-glands; paleae absent

5: Leaves dorsiventral with prominent midrib below, glabrous, cottony pubescent or scabrous but never with dark sunken pit-glands; paleae present

Cassinia

3: Pappus of shortly toothed bristles

6. Paleae present (or if absent, florets 1-3 per capitulum); often aromatic shrubs with a resinous or 'curry' smell; phyllaries all with incurved tips

6: Paleae absent (florets rarely as few as 3, usually 8-10 or more); usually not aromatic; phyllaries all with incurved tips or innermost spathulate with spreading petaloid tips Ozothamnus

\section{Generic relationships within Asteraceae-Gnaphalieae}

The two major papers relevant to how this new genus fits in the Gnaphalieae are Anderberg (1991) and Bayer et al. (2002).

Anderberg (1991) published a number of trees where of all of the above genera (obviously excluding Paenula) were in the Cassiniinae. Unfortunately Anderberg included within his concept of Haeckeria species that are now considered to belong in Ozothamnus (H. pholidota), and Cassinia (H. ozothamnoides). This was reflected in his prophetic statement (p. 87) under Haeckeria that "the genus appears to be polyphyletic". Despite this, it is interesting to note that his strict consensus tree for Cassiniinae (Fig. 12, p. 32) shows Haeckeria + Apalochlamys as sister taxa to Ixodia + Odixia, and this group of four genera sister to Ozothamnus, and that combined clade in turn sister to Cassinia. Other analyses omitted Haeckeria and are thus uninformative. On morphological grounds, the inclusion of Apalochlamys in Anderberg's subclade of Apalochlamys, Haeckeria, Ixodia and Odixia seems to me problematical, but the grouping of the other three genera is credible morphologically. I would place Paenula in this subclade.

Bayer et al. (2002) provided a different set of trees based on molecular sequence data. These trees appeared to show that Ixodia and Haeckeria were situated on widely different branches (branches E and G, Fig. 1, p. 807). However, the Bayer et al. analysis sequenced only one individual from 'Haeckeria', and unfortunately this individual was 


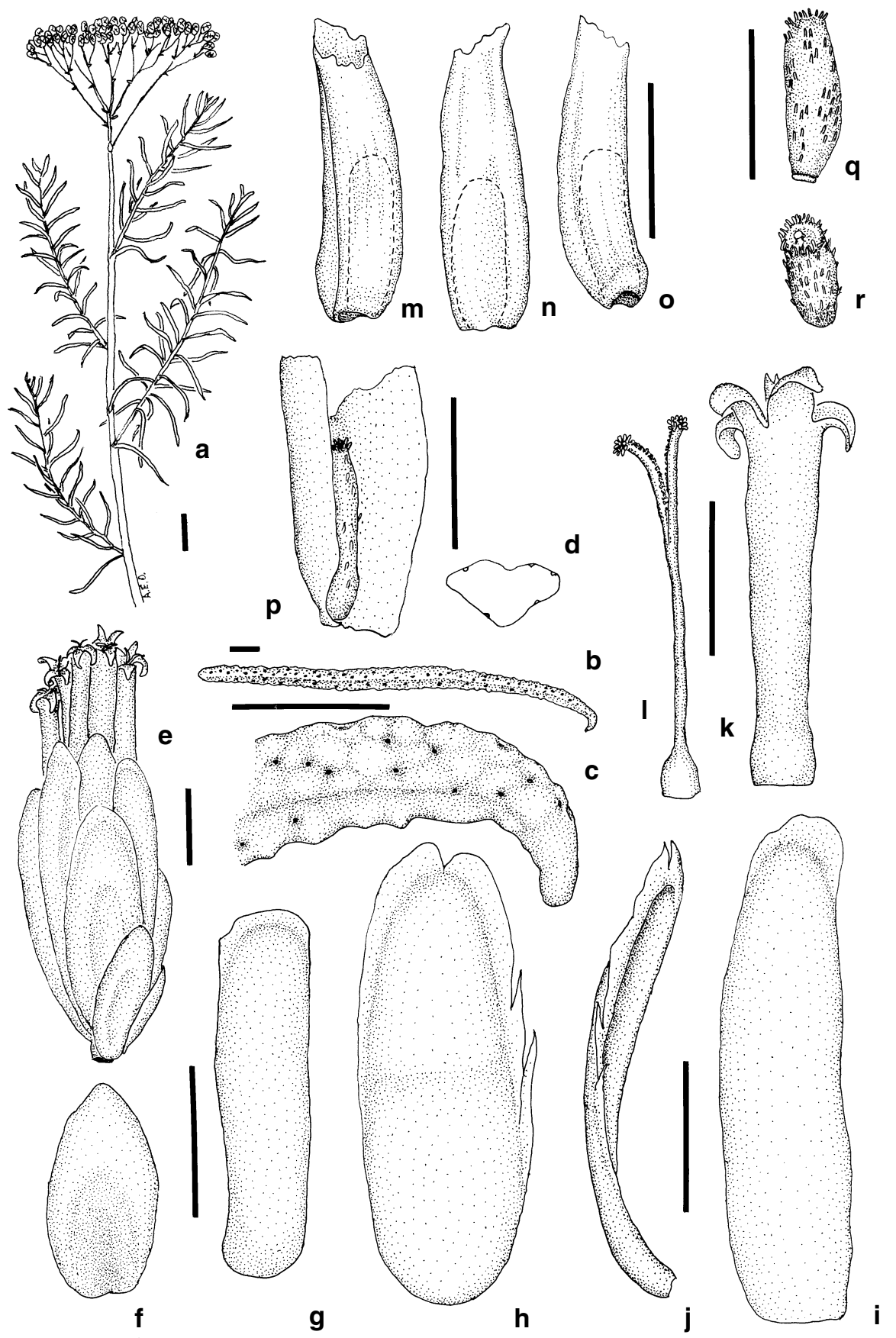

Fig 1. Paenula storyi, a, habit; b, leaf; c, leaf tip; d, diagrammatic TS of leaf; e, capitulum; $\mathbf{f}-\mathbf{i}$, phyllaries from outer to inner, dorsal views; $\mathbf{j}$, phyllary, lateral view of $(\mathbf{h}) ; \mathbf{k}$, corolla; $\mathbf{l}$, style and stylopodium; $\mathbf{m}$, achene enclosed in palea, axial view; $\mathbf{n}$, same, dorsal view; $\mathbf{o}$, same, lateral view; $\mathbf{p}$, achene unusually only partly sheathed by palea; $\mathbf{q}$, achene, lateral view; $\mathbf{r}$, achene oblique apical view. Scales $=1 \mathrm{~cm}$ (a) or $1 \mathrm{~mm}(\mathrm{~b}-\mathrm{r})$. All drawings by author, based on Story 7587 . 
from a taxon that is in fact an undescribed species of Cassinia (Orchard 2004). Thus the analysis provides molecular support for my segregation of this taxon (on morphological criteria) as a Cassinia (the Bayer et al. analysis placed it as sister to Cassinia, represented by a collection of C. longifolia), but does not provide any indication of the real relationships of Haeckeria to Cassinia or Ixodia, or any indication of where Paenula might fit in this hypothetical phylogeny.

\section{Paenula Orchard, gen. nov.}

Frutices; foliis alternis, teretibus, plusminusve trigonis in sectionis, glandibus inclusis fuscatis depressis; inflorescentiis cymosis, umbelliformibus; capitulis pedunculatis, albis, ovoideis; phyllariis membranaceis vel cartilagineis, parum cucullatis, apicibus petaloideis expansis destitutis; flosculis omnibus bisexualibus, tubularibus; paleis cartilagineis, hyalinis, tubularibus achenia et basis corollae vaginantibus; pappibus destitutis; acheniis exutis in paleam vaginantem.

Shrubs; leaves alternate, terete, \pm trigonous in section, with embedded dark sunken glands. Inflorescence cymose, umbelliform, with pedunculate capitula. Capitula white, ovoid; phyllaries membranous to cartilaginous, slightly hooded, lacking petaloid spreading tips, with undivided stereome; florets all bisexual, tubular. Paleae tough, hyaline, wrapping around and enclosing achene and base of corolla. Pappus absent. Carpopodium well-developed. Achenes shed still enclosed in paleae.

Type: P. storyi Orchard

\section{Paenula storyi Orchard, sp. nov.}

Caules glabri. Folia $20 \mathrm{~mm}$ longa, $1 \mathrm{~mm}$ lata, rugosa glandibus fuscatis depressis in omnis paginis, glabra, sessilia; apice acuto, reflexo, non mucronato. Capitula in pedunculis $2 \mathrm{~mm}$ longis. Capitula $3.0-3.5 \mathrm{~mm}$ longa, $1.5-1.7 \mathrm{~mm}$ lata, ovoidea; phyllariis spiratim dispositis, cucullatis, glabris. Phyllaria externa ovata, $1.2 \mathrm{~mm}$ longa, $0.6 \mathrm{~mm}$ lata. Phyllaria interna oblonga, $2.4-2.8 \mathrm{~mm}$ longa, $0.7-0.8 \mathrm{~mm}$ lata. Flosculi c. 6 per capitulum. Corolla cylindrica, tubo $2.2 \mathrm{~mm}$ longo, $0.4 \mathrm{~mm}$ lato, vix tumido ad basim. Achenium purpureo-brunneum, fusiforme, $1.1 \mathrm{~mm}$ longum, $0.3 \mathrm{~mm}$ latum, trichomatibus gemellis sparsis appressis tectum.

Type: New South Wales: Central Western Slopes: 18 miles [c. $29 \mathrm{~km}$ ] north by east of Rylstone (about 12 miles [c. 19 km] S.S.E. of Wollar) R. Story 7587, 18 Mar 1961, holotype NSW232395.

Stems glabrous, weakly longitudinally ribbed. Leaves $20 \mathrm{~mm}$ long, $1.0 \mathrm{~mm}$ wide, rugose with dark sunken glands on all surfaces, glabrous, sessile, not stem clasping; tip acute, reflexed, not mucronate. Inflorescence slightly domed. Capitula on peduncles $2.0 \mathrm{~mm}$ long; peduncles and inflorescence branches subtended by keeled deltoid bracts $1.0 \mathrm{~mm}$ long. Capitula $3.0-3.5 \mathrm{~mm}$ long, $1.5-1.7 \mathrm{~mm}$ diam., ovoid; phyllaries spirally arranged, all somewhat hooded, incurved at tip. Outer phyllaries ovate, $1.2 \mathrm{~mm}$ long, $0.6 \mathrm{~mm}$ wide, glabrous; stereome green, drying brown in lower two thirds; opaque white in upper one third and on wings. Inner phyllaries oblong, $2.4-2.8 \mathrm{~mm}$ long, $0.7-0.8 \mathrm{~mm}$ wide, glabrous, with poorly defined green-brown stereome in lower half to two thirds; upper part and wings white opaque. Paleae cartilaginous; occasional outer paleae oblong, hyaline, $2.1 \mathrm{~mm}$ long, $0.6-0.7 \mathrm{~mm}$ wide, longitudinally fluted, with truncate erose tip; most paleae enveloping base of florets and achenes in a stiff 2-lipped tunic. Florets c. 6 per capitulum, all bisexual. Corolla cylindrical; tube $2.2 \mathrm{~mm}$ 
long, $0.4 \mathrm{~mm}$ wide, scarcely swollen at base; corolla lobes deltoid, $0.4 \mathrm{~mm}$ long, reflexed, glabrous. Anthers $1.25 \mathrm{~mm}$ long incl. $0.13 \mathrm{~mm}$ deltoid appendage; anther tails filamentous, $0.25 \mathrm{~mm}$ long. Style $2.0 \mathrm{~mm}$ overall, divided into 2 branches in upper $0.9 \mathrm{~mm}$; stylopodium transparent, conical, $0.25 \mathrm{~mm}$ long, very minutely rugulose. Style arms truncate, with well developed brush of clavate hairs. Achene purple-brown, fusiform, $1.1 \mathrm{~mm}$ long, $0.3 \mathrm{~mm}$ diam., with sparse appressed twin hairs for entire length, and a denser ring of hairs apically.

Distribution: New South Wales, Central Western Slopes. Known only from the type specimen, collected SSE of Wollar.

Ecology: Found on a nephaline hill, with Cassinia quinquefaria (Story 7577) and Eucalyptus albens dominant. Other material collected at the same time and place comprised Eucalyptus goniocalyx (Story 7574), Eucalyptus laevopinea (Story 7575), Grevillea ramosissima subsp. ramosissima (Story 7576), Eucalyptus blakelyi (Story 7578) Eucalyptus dawsonii (Story 7579) and Muellerina bidwillii (Story 7580). Fruits were present in mid-March. At or immediately after seed shed, capitula abscise below the phyllaries, leaving the small subtending bracts and peduncles still attached to the twiggy remains of the inflorescence.

Etymology: The generic name paenula is a word used by Cicero to describe a coat without sleeves and close to the body, worn on a journey, i.e. a kind of close-fitting cloak. It alludes to the distinctive tightly cloaked fruits of this taxon. The species epithet commemorates the original discoverer, Robert Story, ecologist (1913-1999).

\section{Notes}

It may be argued that this plant really represents an Haeckeria which has retained its paleae. After all, in Haeckeria punctulata and $H$. cassiniiformis, the character of the missing paleae can not be determined, except by analogy. Wakefield (1951) and Orchard (2004) have noted that in Cassinia, which differs from Haeckeria in usually having a pappus and paleae, the paleae are apparently absent in capitula with only 1,2 or 3 florets. In these inflorescences it is argued that the paleae (situated on the abaxial side of the florets) are adjacent to and indistinguishable from the inner phyllaries. Only in capitula with more than 3 florets will paleae be interposed between adjacent florets. By analogy, if the few-flowered capitula of Haeckeria have paleae, then they must be similarly indistinguishable from the inner phyllaries and thus \pm flat. Therefore in Haeckeria the paleae are either completely absent (as most believe), or \pm flat and resembling the inner phyllaries. In either case, the situation differs from that in Paenula where the paleae are sheathing.

Paenula storyi was searched for unsuccessfully in February 2004 near its original place of discovery, in the vicinity of Growee Gulph, and again, unsuccessfully, in early March 2004 on Barigan Road, SSE of Wollar. The latter seems the most likely source of Story's original collection - the respective reference distances from Rylstone and Wollar turn out to miss each other by about 10 kilometres. At about the correct distance (12 miles) from Wollar there is in fact a small hill composed largely of basaltic boulders, on the property of Mr John Jakes, "Derowen". This hill bears a remnant scrub of Eucalyptus albens, Cassinia quinquefaria and Bursaria spinosa on its summit, with occasional legumes and herbaceous Asteraceae, but there was no sign of Paenula. A few kilometres 


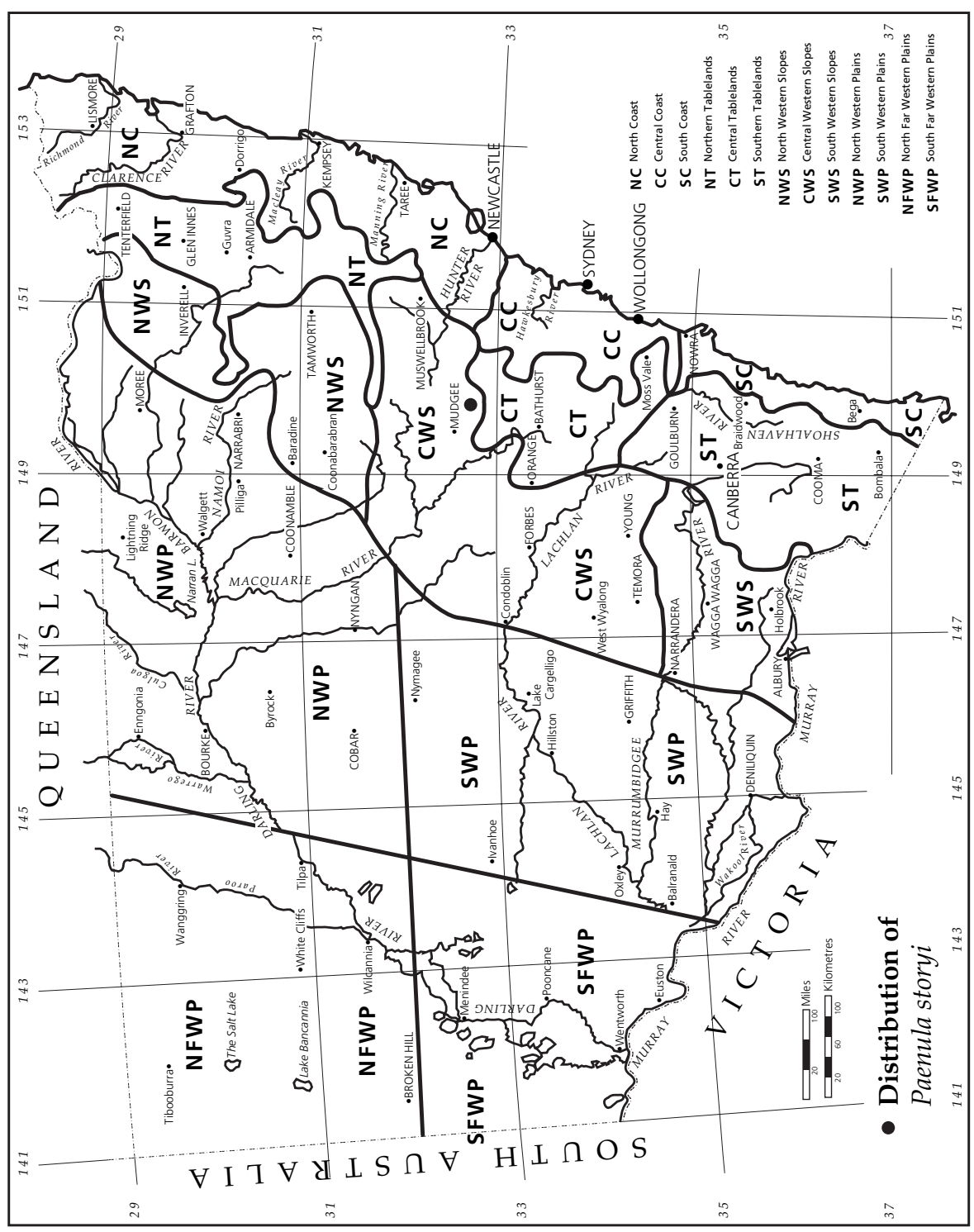

Fig. 2. Distribution of Paenula storyi, New South Wales. 
further along the same valley there is a volcanic plug, which now has only a grassy covering. All other hills in the near vicinity seemed to be mainly sandstone. The upper slopes of these (generally larger) hills are covered with a dense forest of Eucalyptus spp., Callitris, Xanthorrhoea and Cassinia quinquefaria. No material resembling Paenula was discovered in a vegetation survey of the adjacent Merriwa area by McRae \& Cooper (1985).

This lack of success in rediscovering Paenula may signify nothing more than that the plant is short-lived. Reference has already been made to the morphological similarity between Paenula and the two Haeckeria species. Several collections of Haeckeria bear notes on their ephemeral nature. Haeckeria species may appear in abundance after major disturbance such as fire or 'chaining' of the mallee scrub in which they grow. However they are usually senescent in $4-5$ years and disappear completely within 10 years, awaiting the next disturbance. It is very possible that Paenula is behaving similarly and will be re-discovered in the Wollar/Rylstone area after a future disturbance.

It has been suggested by readers of earlier drafts of this paper that Paenula storyi might also be explained as a short-lived hybrid or polyploid, but those making this suggestion offer no suggestions as to parent taxa or (diploid) ancestor. However, the possibility is worth exploring. My morphological analysis suggests that the two most diagnostic characteristics of this taxon are its cloaking paleae (in the Cassiniinae shared only with Ixodia, the nearest representatives of which are currently found $1000 \mathrm{~km}$ to the west of Paenula), and the trigonous leaves with sunken pit-glands (in the Cassiniinae shared only with Haeckeria s. str., the nearest representatives of which are currently found 900 $\mathrm{km}$ south-west of Paenula). The only Cassiniinae found near the location of Paenula are Ozothamnus and Cassinia species, none of which exhibit either of these character states. While this does not exclude the possibility of Paenula having arisen through a hybridisation or polyploidy event in the distant geological past, when Haeckeria and Ixodia may have been present in NSW, it begs the question of how long a selfperpetuating taxon needs to exist before it can be recognised as a genus in its own right? I believe that a recent hybrid or polyploidy origin for Paenula is extremely unlikely.

\section{Acknowledgments}

The author is grateful to his wife Theresa, patient and observant field assistant on numerous field trips in search of Cassinia and related taxa, and who searched the AVH database for other Story collections from the type locality. Laurie Adams supplied background information on Robert Story. The Centre for Plant Biodiversity Research, CSIRO, Canberra, kindly provided excellent institutional support for this study and related fieldwork. Brendan Lepschi patiently joined me in the search for Paenula SSE of Wollar. The author is particularly grateful to John Jakes, owner of 'Derowen', for hospitality and advice during the unsuccessful search on his property. I am also grateful to Barry Conn, Karen Wilson and John Benson of the National Herbarium of NSW, for background information on Story's collections and survey of 1961. Finally, I am very grateful to the National Herbarium of NSW for including this interesting material in my loan of Cassinia. 


\section{References}

Anderberg AA (1991) Taxonomy and phylogeny of the tribe Gnaphalieae (Asteraceae), Opera Botanica 104: 5-195.

Bayer RJ, Greber DG \& Bagnall NH (2002) Phylogeny of Australian Gnaphalieae (Asteraceae) based on chloroplast and nuclear sequences, the $\operatorname{trnL}$ Intron, $\operatorname{trn} L / \operatorname{trnF}$ Intergenic Spacer, $m a t K$, and ETS. Systematic Botany 27(4): 801-814.

Copley PB (1982) A taxonomic revision of the genus Ixodia (Asteraceae). Journal of the Adelaide Botanic Gardens 6: 41-54.

McRae RHD \& Cooper MG (1985) Vegetation of the Merriwa area, New South Wales. Cunninghamia 1(3): 351-369.

Orchard AE (1981) The generic limits of Ixodia R.Br. ex Ait. (Compositae - Inuleae). Brunonia 4: $185-197$.

Orchard AE (2004) A reassessment of the genus Haeckeria (Asteraceae - Gnaphalieae), with definition of a new species in Cassinia. Australian Systematic Botany 17: 447-467.

Wakefield NA (1951) Some notes on Cassinia with description of a new species. Victorian Naturalist 68: 69-70.

Manuscript received 19 May 2004, accepted 11 July 2005 